\title{
Editorial: To Write Very Little
}

In 1919 the young T.S. Eliot wrote to a former philosophy teacher of his 'there are only two ways in which a writer can become important to write a great deal, and have his writings appear everywhere, or to write very little.' Eliot announced, possibly partly to excuse his defection from philosophy and from academe, that he intended to follow the latter path, and to restrict himself to 'printing' but two or three poems a year.

Writing very little is not currently well thought of in the academy or in professional philosophical circles. Writing the same thing over and over again, with minor variations, modifications, additions, revisions and amplifications has become for those who cannot write different things the very touchstone of professionalism. Even in the case of those who are able to write different things, length and ever more impenetrable detail often obscure the point, or in some cases, the barrenness and even the nakedness of the underlying thought.

Given the nature of academic life it would be pointless to blame individuals for this state of affairs, and uncharitable to boot. After all most have families to feed and mortgages to pay. Much of what is written is, in a certain sense, worthy. And in a journal of academic articles it would be unbecoming to complain of publishing per se.

The examples of Socrates and Wittgenstein aside, we could also question the extent to which in philosophy writing, or at least publishing, very little has generally been a method much favoured by the great philosophers (even if writing a great deal is certainly not sufficient for greatness). On the other hand when the average philosophical article is said to be read by only a small handful of people, deservedly or not, it would not be unbecoming for us all to ask ourselves whether we really have anything to say which is really worth hearing, before yet another assault on the keyboard. Philosophically there may sometimes be more to be said for quietly reading or thinking, or having a conversation with colleagues, or talking to students, or just going for a walk. In other words, doing the sorts of thing academics used to do within living memory, when academic life was less 'professional', more collegial, and not necessarily less philosophical. 